\title{
Production and Quality Assessment of Value-added Fast Foods by Using Low-cost Fish in Bangladesh
}

\author{
Shoriful Islam¹, MD. Jahirul Islam², Mustasim Famous ${ }^{4}$, Mohammad Amzad \\ Hossain $^{3, *}\left(\mathbb{D}\right.$, Mohammad Mehedi Hasan Khan ${ }^{2}$
}

${ }^{1}$ Khulna Agricultural University, Department of Biochemistry and Molecular Biology, Khulna, Bangladesh.
${ }^{2}$ Sylhet Agricultural University, Department of Biochemistry and Chemistry, Sylhet-3100, Bangladesh.
${ }^{3}$ Sylhet Agricultural University, Department of Fish Biology and Genetics, Sylhet-3100, Bangladesh.
${ }^{4}$ Khulna Agricultural University, Department of Livestock Production and Management, Khulna, Bangladesh.

\section{How to cite}

Islam, S., Islam, M.J., Famous, M., Hossain, M.A., Khan, M.M.H. (2021). Production and Quality Assessment of Value-added Fast Foods by Using Lowcost Fish in Bangladesh. Aquatic Food Studies, 1(2), AFS72. https://doi.org/10.4194/AFS72

\section{Article History}

Received 20 November 2021

Accepted 29 December 2021

First Online 03 January 2022

\section{Corresponding Author}

Tel.: -

E-mail: mamzad.fbg@sau.ac.bd

\begin{abstract}
This study was conducted to increase the perception of low-priced aquaculture fish by value addition and to evaluate the sensory, nutritional, and microbial quality of resulting products. Thai-Pangus was used as raw materials to prepare value added products such as fish ball, fish burger and fish singara and it was formulated by adding different ingredients with fish minced followed by cooking. Proximate composition of the prepared value-added products was determined to assess the nutritional quality. A panel of 10 members conducted sensory assessments of the products. Standard plate count method was used to estimate bacterial count. The highest moisture $(65.29 \pm 0.38)$ and crude lipid $(7.91 \pm 0.24)$ percentage were reported in fish ball, while highest (crude protein $(19.13 \pm 0.37)$ percentage was estimated in fish burger $(P<0.05)$. There was no significant $(P<0.05)$ difference in ash content of the products. In both room and refrigerated storage temperatures, the bacterial count of all the products increased significantly as the storage time increased. Initial sensory scores of all fresh products were maximum but with the progress of storage period all the sensory qualities of the products were decreased especially at room temperature. However, refrigerated temperature $\left(4^{\circ} \mathrm{C}\right)$ kept all the products' quality stable.
\end{abstract}

\section{Introduction}

Fish has been broadly perceived as an honorable wellspring of protein. Fish has long been regarded as a considerable source of protein also is rich in marinederived omega-3 long-chain polyunsaturated fatty acids (Hossain et al., 2017; Hossen et al., 2021; Mian et al., 2017). The popularity of fishery products in the diets of many countries has increased due to recommendations for reducing total levels of dietary fat. Likewise, in Asian nations, because of expanding consciousness of the customers on medical problems, utilization of fish and fishery products are expanding step by step. Besides, in these days the preference of the consumers has considerably focused on fast-food consumptions since there has been a rapid urbanization and an increase in the number of working women. As a result, during the most recent five years, a ton of cheap food shops have been opened in city, suburb, and modern spaces of the country. With the modernization of the society, people in Bangladesh have been going out of the house more. Teenagers, young working people and students are more in search of ready to eat food. The demand for ready to eat as well as prepared to cook items are continuously developing because of their comfort. In this perspective, value addition and diversification of fish products will help satisfy the ever changing and diverse demands of the consumers. Value addition is the most promising field in the food industry. Value added to a product or service through a specific process that 
can change the properties of raw materials is called added value, and the product produced in this way is called value-added product. Different types of valueadded products such as fish fillets, fish balls, fish burgers, fish sticks, and other surimi-based products can be made from fish (Akter et al., 2013). Value added fish products made from different fish mince could ensure the maximum resource utilization of Bangladesh as well as food security (Hoque et al., 2021). The technology for producing value added fish products is very simple and it requires less complex machinery. Commercial fish farmers can produce this product in their kitchen and market it locally. Besides, value-added fish products will carry quick advantage to the current fish handling enterprises of the country (Nowsad et al., 1994). Bangladesh is considered as one of the most suitable countries for freshwater aquaculture in the world due to its favorable resources and agricultural climatic conditions (Hossain, 2021; lqbal et al., 2015; Rahman et al., 2020). The subtropical climate, expansive ponds, low agricultural land and, depending on the season, halfenclosed shallow waters create ideal conditions for fish farming (Hasan et al., 2021). The production of freshwater aquaculture of Bangladesh ranks fifth in the world after China, India, Vietnam, and Indonesia (FAO, 2014). In 2016-17, fish production of Bangladesh was 3.548 million $\mathrm{MT}$, and more than half $(56.44 \%)$ of this production came from the aquaculture sector (DoF, 2017). In Bangladesh, bighead carp (Aristichthysnobilis), common carp (Cyprinuscarpio), grass carp (Ctenopharyngodonidella), silver carp (Hypophthalmichthysmolitrix) and sutchi catfish (Pangasianodon hypophthalmus), locally identified as Thai-Pangus are commonly known low-cost exotic species (Chowdhury et al., 2019). This species is exotic and has been introduced to Bangladesh over the past few decades to supplement fish production. All these exotic fishes contributed significantly to commercial aquaculture in Bangladesh and accounted for an average of $28 \%$ of total aquaculture production (De Silva et al., 2006). In 2013-14, the production of pangus was $371,068 \mathrm{MT}$ which contributed around $13 \%$ of total inland water production thus it made pangus the second largest contributor in this sector (FRSS, 2015). However, most of these low-cost fish remain undeveloped due to their inherent problems of unattractive color, taste, texture, small size, and high fat content. For example, the presence of intramuscular bones in carp lowers consumer preference for these species (Gopakumar, 1997). Correspondingly, Thai-Pangus are extensively cultured in Bangladesh, and it has a great potential due to its faster growth rate. But in the peak season, the market price of these fishes often declines due to offflavor, high fat content and abundance of their production. Henceforth, there is a need to foster some comfort items from the meat of minimal expense fish to upgrade their buyer adequacy (Akter et al., 2013). Mechanical bone removal to recover flesh and establishment of value-added products is perhaps the most promising approach. There are many possibilities to develop products using minced meat from low-cost aquatic resources. So, if the farmer can use this lowpriced fish for the preparation of such types of products, they can bring in attractive cash by selling the products (Vanitha et al., 2013). Fish ball, fish burger, fish finger, fish patties are some of the most important value-added fish products which are very popular to urban consumers and young generations. It has been suggested that convenient products can be produced from low-cost fish. Unfortunately, although value added products prepared from beef and poultry are served to the fast-food shops in the market, value added fish products are not produced commercially in Bangladesh. Earlier, some studies were conducted to produce value added fish products from low-cost fish and marine fish (Nowsad et al., 2004, Ejaz et al., 2009, Akter et al., 2013; Vanitha et al., 2013). However, except for some initiative, production at business level would not have been imaginable because of the absence of business ventures at that time. Considering the above real factors, the current study was therefore, planned and led to define and get ready value-added fish products, for example, fish ball, fish burger and fish finger from Thai-Pangus for better usage of this low-priced fish species and to assess the nutritional quality, the bacterial count and sensory quality of these items during various capacity conditions.

\section{Materials and Methods}

The present study was carried out to improve the quality of low-cost fish and its storage condition by various value additions. The primary objectives of the study were to prepare the value-added fish products such as fish burger, fish ball and fish singara using ThaiPangus fish as raw materials and to assess their sensory, nutritional, and microbial quality at different storage conditions.

\section{Experiment Location and Period}

The research work was performed in the different laboratories and processing units of Sylhet Agricultural University (SAU), Sylhet, Bangladesh.

\section{Preparation of Value-added Products}

\section{Collection of Fish and Preparing Mince}

Fresh Thai-Pangus fish was purchased from the Tilagor Bazar and Majortila Bazar of Sylhet Sadar. Immediately after purchasing, the fish was preserved properly with crushed ice in an insulated box and transported to the laboratory. The average size of the fish was $42 \pm 2.50 \mathrm{~cm}, 1.65 \pm 0.35 \mathrm{Kg}$ and the price of the fish was Tk $100 \pm 15$ per $\mathrm{Kg}$. Then fish were washed in clean water, beheaded, eviscerated, and peeled. The peeled fishes were filleted and deboned manually in 
iced condition. The mince was then prepared through a $1 \mathrm{~mm}$ inlet diameter mesh plate with mechanical mincer to remove all bone and connective tissue from the muscle. All utensils used in the experiment were washed and stored in a cool place $\left(4^{\circ} \mathrm{C}\right)$. Crushed ice was used to maintain the required temperature during the preparation (Figure 1).

\section{Formulation of Fish Ball}

The materials used to make the fish ball are shown in Table 1. First, ginger, garlic, chili powder and onion are fried slightly with oil. These fried spices mixed properly with minced meat. Then the whole mixture is fried again slightly. Then fried minced fish was coated with egg followed by biscuit's crumbs. Finally, the ball shape was given. Lastly the fish ball was prepared for frying in fresh soybean oil. Then prepared fish balls were kept in the refrigerator $\left(4^{\circ} \mathrm{C}\right)$ and room temperature $\left(28^{\circ} \mathrm{C}\right)$. The whole procedure is shown in figure 2.

\section{Formulation of Fish Singara}

The materials used to make the fish singara are shown in Table 2. At first ginger, garlic, green chili powder and onion were fried lightly with oil. These fried spices were mixed properly with minced meat. Then the whole mixture was fried again slightly. Wheat flour and small amounts of oil were mixed properly to prepare dough with mixing of water. Then the dough was spread to a thin sheet. Finally, singara shape was given to the fine sheet of wheat dough and meat was poured inside it. Lastly, the singara was prepared by frying in refined oil. Freshly prepared fish singaras were packed with a polyethylene bag and kept at refrigerator $\left(4^{\circ} \mathrm{C}\right)$ and room temperature $\left(28^{\circ} \mathrm{C}\right)$. The whole procedure is shown diagrammatically in figure 3 .

\section{Formulation of Fish Burger}

The ingredients utilized for the preparation of fish burgers are given in Table 3. The mince from Thai Pangus fish muscle was ground with $2 \% \mathrm{NaCl}, 2 \%$ oil, $0.6 \%$ sugar, $2 \%$ flavors (onion, garlic, ginger, green stew glue and hot flavors. The mixing was done for the most part for 5-7 minutes. The entire dough was stuffed into a steel outline. The size of every burger patty was $(6.5 \times 6 \times$ $0.5 \mathrm{~cm})$. The steel outline was set on a wooden plate. One more wooden plate was fixed on the edge and held firmly with stray pieces to pack the material kept in the

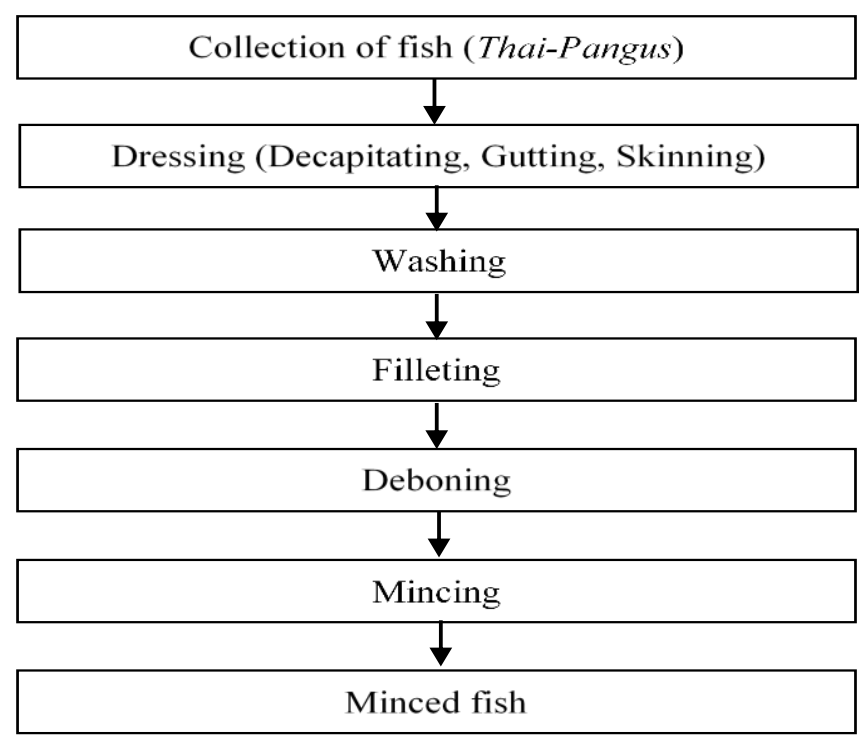

Figure 1. Diagram of processing and mince preparation from collected fish

Table 1. Ingredients of fish ball with their percentage.

\begin{tabular}{lcc}
\hline Sl. No. & Materials & Amount (\%) \\
\hline 1 & Minced fish & 75 \\
2 & Egg & 3.5 \\
3 & Biscuit crumbles & 5 \\
4 & Ginger & 1 \\
5 & Turmeric & 1 \\
6 & Water & 2.5 \\
7 & Edible oil & 3 \\
8 & Garlic powder & 4 \\
9 & Onion flakes & 2 \\
11 & Salt & 2 \\
\hline
\end{tabular}


Table 2. Ingredients of fish singara with their percentage

\begin{tabular}{lcc}
\hline SI. No. & Materials & Amount (\%) \\
\hline 1 & Minced fish & 40 \\
2 & Salt & 2 \\
3 & Onion & 3 \\
4 & Garlic & 3 \\
5 & Ginger & 2 \\
6 & Turmeric & 1 \\
7 & Chilli powder & 2 \\
8 & Pepper & 1 \\
9 & Bread crumbles & 1 \\
10 & Flour & 45 \\
\hline
\end{tabular}

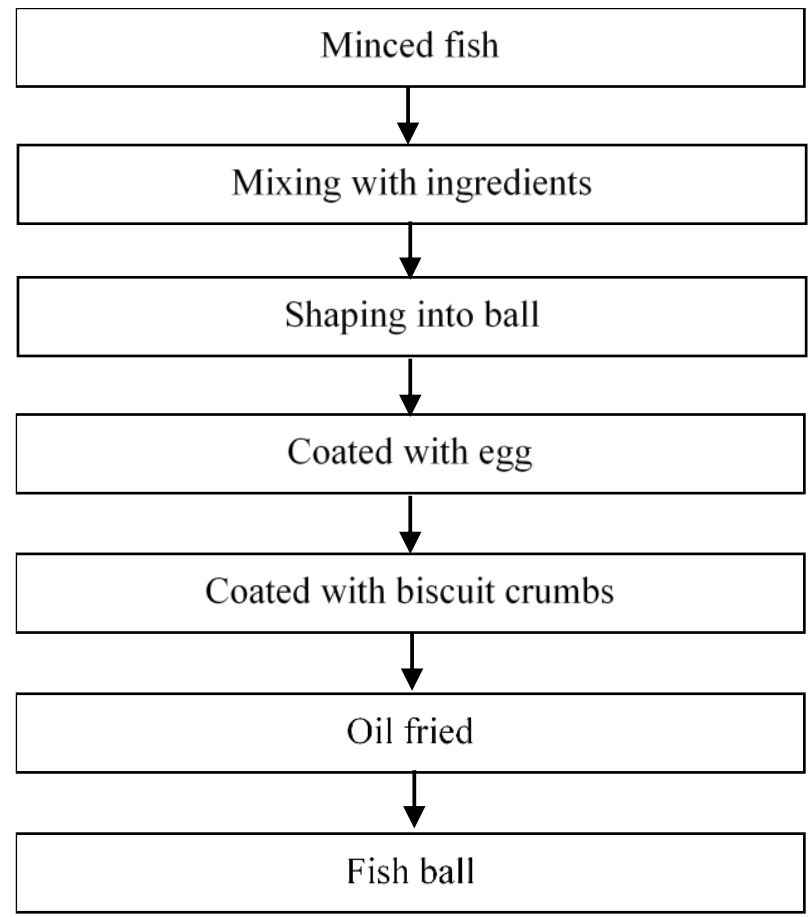

Figure 2. Diagram representing fish ball processing from minced fish.

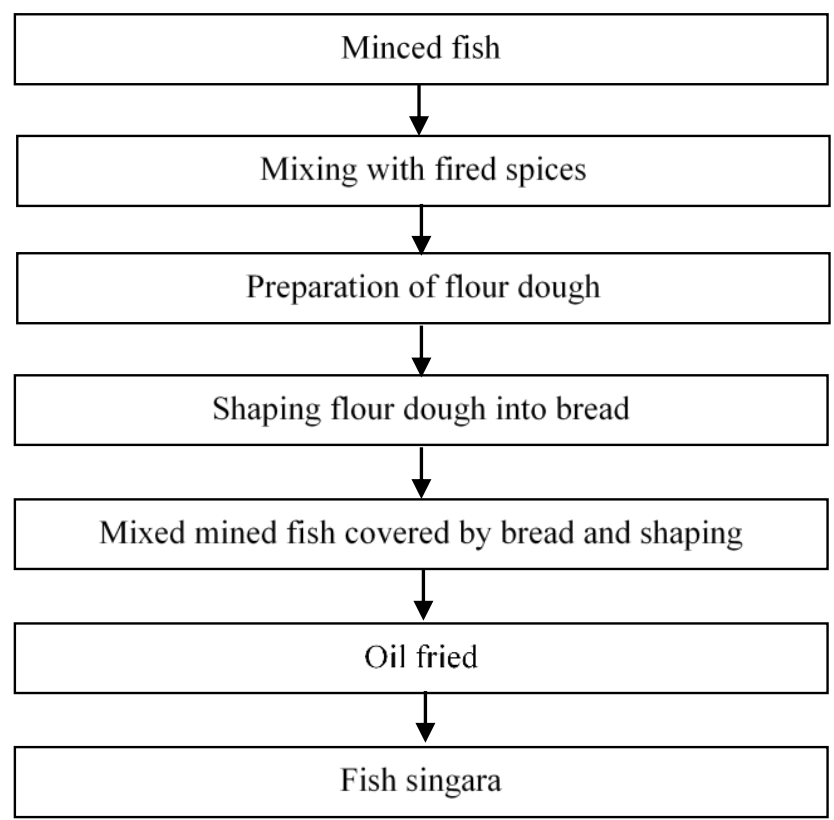

Figure 3. Diagram representing fish singara processing from minced fish. 
steel outline in the middle of the two wooden plates. Then the patties left for some time for seasoning. After seasoning, the patties were separated from the steel frame and dipped in a batter formulation. Then, it was fried in dip-oil. Freshly prepared fish burgers were gathered with a polyethylene sack and kept at cooler $(50 \mathrm{C})$ and room temperature $\left(28^{\circ} \mathrm{C}\right)$. The entire method is shown diagrammatically in Figure 4.

\section{Proximate Analysis}

Proximate composition of freshly prepared fish ball, fish burger and fish singara in triplicates were determined. Proximate analysis of moisture, crude protein, lipids, and ash were performed according to the methods provided in AOAC (1990). Proximate analysis of moisture, crude protein, lipid and ash of these burgers were analyzed from their bread part, meat part and as whole.

\section{Sensory Analysis}

From the stored lot, fish balls, fish burgers and fish singaras were randomly chosen, and from each packed sample were analyzed to evaluate sensory attributes. Samples were drawn four times within a period of 72hours with a 24-hour interval between samplings. A panel of 10 members of teachers and students conducted sensory analysis of the products as described by Nowsad et al. (2000). Prior to analysis, panel members were familiarized with the properties of fish burger, fish ball and fish singara and the instructions relating to scoring of the samples. All prepared fish burger, fish ball and fish singara were served to 10 panel members to evaluate the sensory attributes (colour, odor, taste, texture, general acceptability) of the samples by using a 9-points descriptive scale. According to the scoring table, 'high quality' indicated the scores between 7-9, 'moderate quality' indicated scores between 4-6 and scores between 1- 3 indicated the limit of 'unacceptability'.

\section{Microbial Analysis}

From the stored lot, fish balls, fish burgers and fish singaras were conveniently chosen, and from each packed sample were analyzed in triplicate for bacterial count determination as described in the following sections. Samples were selected four times within a period of 72 hours with a 24-hour interval between samplings.

Table 3. Ingredients of fish burger with their percentage.

\begin{tabular}{lcc}
\hline Sl. No. & Materials & Amount (\%) \\
\hline 1 & Minced fish & 55.0 \\
2 & Chilled water & 35.0 \\
3 & Chopped onion & 2.5 \\
4 & Onion flakes & 4.0 \\
5 & Vegetable oil & 2.5 \\
6 & Salt & 1 \\
\hline
\end{tabular}

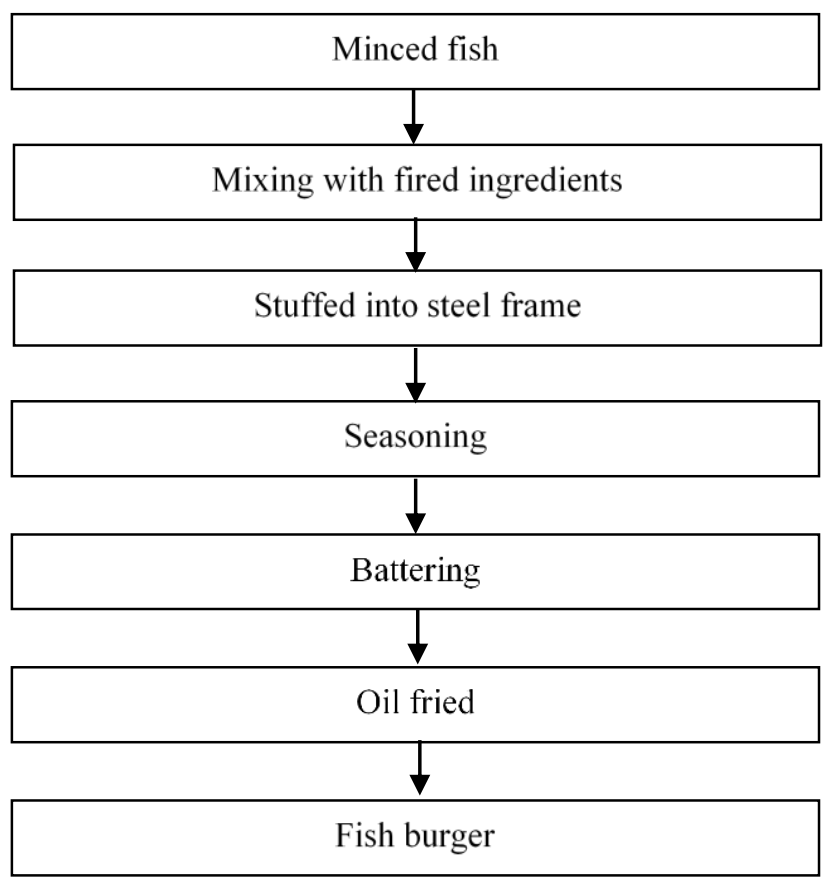

Figure 4. Diagram of representing fish burger preparation from minced fish. 


\section{Preparation of Media}

\section{Solid Media for Culture}

The samples were subjected to bacteriological analysis including Plate count agar (PCA), EosinMethylene Blue (EMB) and Salmonella-Shigella (S-S) agar media. Properly and poured into sterile Petri-dishes (10 $\mathrm{ml}$ in each petri-dish) and allowed to solidify. These were then incubated overnight at $37^{\circ} \mathrm{C}$ to confirm sterility and used for culture characterization or stored at $4^{\circ} \mathrm{C}$ in a refrigerator for further use.

\section{Salmonella-Shigella (S-S) Agar Media}

This medium was also used to detect the growth of E. coli. About $6 \mathrm{~g}$ of dehydrated Salmonella shigella agar was suspended in $100 \mathrm{ml}$ of cold distilled water, placed in a conical flask, and heated until boiling to completely dissolve the medium. After sterilization by autoclaving, $10 \mathrm{ml}$ of the medium was poured into a sterile glass Petri dish (medium size) and $15 \mathrm{ml}$ was poured into a sterile glass Petri dish (large size) to form a thick layer. After drying, the lid of the Petri dish was partially removed while the medium was solidified for about 2 hours. Sterility of the medium was determined by storing Petri dishes in an incubator at $37^{\circ} \mathrm{C}$ overnight and then using for culture characterization or at $4^{\circ} \mathrm{C}$ in the refrigerator for further use (Carter, 1979).

\section{Eosin Methylene Blue (EMB) Agar}

For the preparation of this medium, $36 \mathrm{~g}$ of EMB agar powder was suspended in 1 liter of distilled water placed in a conical flask. The medium was then completely dissolved by heating to boiling point. Sterilized by autoclaving at 15 psi $\left(121^{\circ} \mathrm{C}\right.$.) for 15 minutes, the medium cooled to $50^{\circ} \mathrm{C}$., thoroughly mixed, poured into sterile Petri dishes $(10 \mathrm{ml}$ into each Petri dish) and allowed to solidify. They were then incubated overnight at $37^{\circ} \mathrm{C}$ to confirm sterility and used for culture characterization or stored at $4^{\circ} \mathrm{C}$ in a refrigerator for further use

\section{Sample Preparation}

Fresh fishes were sacrificed to collect additional samples. For this purpose, $25 \mathrm{~g}$ fish samples were taken from the muscles of the fish and uniformly mixed with $225 \mathrm{ml}$ of distilled water in a laboratory blender for a stormer. Each sample was aseptically mixed with sterile distilled water in a ratio of 1:10. The sample was then shaken until a homogeneous suspension was obtained. Afterwards, according to the recommendations of international standardization (ISO, 1995), 10-fold serial dilutions $(1: 10)$ were prepared in the range of $10^{2}$ to $10^{9}$. The diluted samples were then placed in the nutrient broth and mixed well. Thereafter, the sample containing the nutrient solution was put in an incubator and the sample was incubated for 24 hours.

\section{Bacteria Culture and Counting}

All plates in sterile Petri dishes were processed on sterile agar medium for plate counting. Using a micropipette, $0.1 \mathrm{ml}$ aliquots were taken from the sample solutions in various tubes with various dilutions, transfer them to the prepared agar plate under sterile conditions, and lift the top cap to a level sufficient to fit into the edge of the pipette. The sample was then homogenized and carefully spread with a sterile Lshaped fired glass rod over the entire surface of the medium until the sample was dry. Plates were incubated at $37^{\circ} \mathrm{C}$. upside down in an incubator. After 48 hours of incubation, colonies formed in Petri dishes were counted using standard methods. To obtain acceptable values, only plates containing 30 to 300 colonies were considered for counting. Number of bacteria per gram of the sample (CFU/g) was calculated by using the following formula.

$\mathrm{CFU} / \mathrm{g}=$

No. of colonies on petridish $\times 10 \times$ dilution factor $\times$ Volume of total sample solution Wt. of fish sample $(\mathrm{g})$

\section{Data Analysis}

Experimental results were analyzed using the statistical package for the Social Sciences (SPSS) 20 (IBM, 2010). Results were expressed as mean \pm standard deviation (SD). One-way ANOVA method was performed using Duncan's test to find significant differences between storage times.

\section{Results and Discussion}

\section{Proximate Composition Analysis}

Proximate composition of three value added products viz. fish ball, fish burger and fish singara prepared from minced Thai-Pangus are presented in Table 4. Highly significant $(P<0.05)$ differences were

Table 4. Proximate composition of fish ball, fish burger and fish singara prepared from Thai-Pangus.

\begin{tabular}{|c|c|c|c|c|}
\hline \multirow[t]{2}{*}{ Parameters } & \multicolumn{3}{|c|}{ Value Added Products } & \multirow[t]{2}{*}{$P$ value } \\
\hline & Fish Ball & Fish Burger & Fish Singara & \\
\hline Dry matter (\%) & $65.29 \pm 0.38^{c}$ & $60.84 \pm 0.49^{b}$ & $58.64 \pm 0.62^{a}$ & 0.05 \\
\hline Crude Protein (\%) & $17.08 \pm 0.21^{b}$ & $19.13 \pm 0.37 c$ & $15.27 \pm 0.49^{a}$ & 0.05 \\
\hline Ether extract (\%) & $7.91 \pm 0.24^{c}$ & $6.96 \pm 0.23^{b}$ & $5.54 \pm 0.51^{a}$ & 0.05 \\
\hline Ash (\%) & $2.66 \pm 0.32$ & $2.09 \pm 0.26$ & $2.17 \pm 0.26$ & 0.05 \\
\hline
\end{tabular}

*Each value is represented as the mean \pm SD of $n=3$. *Different superscripts in each row represent significant difference $(P<0.05)$. 
observed between dry matter, crude protein and crude lipid contents of fish ball, fish burger and fish singara. Dry matter $(65.29 \pm 0.38)$ and ether extract $(7.91 \pm 0.24)$ percentage of fish balls were significantly $(P<0.05)$ higher than the other two. Crude protein $(19.13 \pm 0.37)$ of fish burger was highest $(P<0.05)$. Significantly $(P<0.05)$ lower moisture, crude protein and crude lipid was observed in fish singara. No significant $(P<0.05)$ difference was found for ash content among the fish ball, fish burger and fish singara. Proximate composition of burgers from three different origins with their bread, meat and as a whole is shown in Table 5. Highly significant $(P<0.05)$ differences were observed for dry matter, crude protein, ether extract and ash contents of burgers from three different origins. Dry matter, ether extract and ash percentage were significantly $(P<0.05)$ higher in beef burgers than others two.

A study by Pires et al., (2017) reported 17 to $19 \%$ protein in fish burgers. As burger is consumed due to protein, higher protein value showed its superiority than other two burgers. Again, Beef burgers contained a very high amount of fat, though fatty acid composition was not checked but beef contained mostly saturated fatty acid (Youssef et al., 2012). The higher amount of fat in beef burgers than normal beef meat indicates that additional fat during burger preparation can cause higher fat in burgers. Most of the commercial burger sellers add palm oil during preparation of burgers that can cause more harm to the health. Lithi et al., (2020) reported that ash content of mince-based fish burgers from tilapia (Oreochromis mossambicus) increased at a significant rate which is not in accordance with the study. Burgers prepared from fish had higher moisture, protein, lipid, and ash content than fish mince but all parameters except ash content decreased gradually as frozen storage period progressed (Lithi et al., (2020). Due to dehydration during frozen storage the total moisture content both in fish mince and burger was reduced (Ninan et al., 2008).

\section{Sensory Analysis}

Table 6 shows changes in color, odor, taste, texture, and overall acceptability of Thai-Pangus fish balls stored at room temperature $\left(28^{\circ} \mathrm{C}\right)$ and refrigerated $\left(4^{\circ} \mathrm{C}\right)$. Sensory qualities decreased with a progression of storage time $(\mathrm{P}<0.05)$ at room temperature. The first noticeable fresh sweet odor of the fish balls gradually became pungent, followed by a sour odor, accompanied by a moist, slimy surface on which the fungus grew at $28^{\circ} \mathrm{C}$ for 72 hours, indicating strong bacterial growth. A foul odor was observed after 48 hours of storage and fungal growth was observed after 72 hours of storage. A slight pungent odor was felt after 24 hours. On the contrary, at refrigerated temperature $\left(4^{\circ} \mathrm{C}\right)$ the product was more stable. The color, odor, taste, and overall acceptability did not change considerably even after 72 hours $(P>0.05)$. Fungal growth also was not observed after 72 hours. Similarly, the variations in color, odor, taste, texture, and overall acceptability of fish burgers prepared from Thai-Pangus stored at room temperature $\left(28^{\circ} \mathrm{C}\right)$ and refrigerated temperature $\left(4^{\circ} \mathrm{C}\right)$ are presented in Table 7. Fresh fish burgers received an initial score of 9 and rated as high quality. Sensory features were found reduced prominently $(P<0.05)$ with the increase of storage time

Table 5. Proximate composition of different burger with their parts.

\begin{tabular}{|c|c|c|c|c|c|}
\hline Types of Burgers & Part of Burger & DM (\%) & Ash (\%) & $\mathrm{CP}(\%)$ & EE (\%) \\
\hline \multirow[t]{3}{*}{ Fish } & Bread & $71.25 \pm 0.02$ & $0.78 \pm 0.04$ & $9.67 \pm 0.31$ & $2.15 \pm 0.27$ \\
\hline & Meat & $56.52 \pm 0.65$ & $1.96 \pm 0.01$ & $22.19 \pm 0.29$ & $28.54 \pm 0.83$ \\
\hline & Whole & $63.27 \pm 1.70$ & $1.56 \pm 0.18$ & $17.45 \pm 0.45$ & $13.92 \pm 0.09$ \\
\hline \multirow[t]{3}{*}{ Chicken } & Bread & $71.25 \pm 0.02$ & $0.78 \pm 0.04$ & $8.70 \pm 0.23$ & $2.15 \pm 0.27$ \\
\hline & Meat & $52.18 \pm 0.32$ & $2.15 \pm 0.01$ & $19.88 \pm 0.48$ & $20.30 \pm 0.51$ \\
\hline & Whole & $62.37 \pm 1.08$ & $1.48 \pm 0.12$ & $13.66 \pm 0.30$ & $15.12 \pm 0.64$ \\
\hline \multirow[t]{3}{*}{ Beef } & Bread & $78.29 \pm 0.31$ & $1.15 \pm 0.04$ & $9.67 \pm 0.31$ & $3.01 \pm 0.05$ \\
\hline & Meat & $72.96 \pm 0.83$ & $2.15 \pm 0.07$ & $14.38 \pm 0.54$ & $35.85 \pm 0.41$ \\
\hline & Whole & $67.69 \pm 0.40$ & $1.81 \pm 0.16$ & $12.46 \pm 0.06$ & $17.56 \pm 0.35$ \\
\hline$P$ value & & 0.05 & 0.05 & 0.001 & 0.001 \\
\hline
\end{tabular}

Table 6. Effect of storage temperature and period on sensory quality of fish ball prepared from Thai-Pangus ( $n=10)$. Data expressed as mean $\pm \mathrm{SD}$.

\begin{tabular}{lcccccc}
\hline Storage temperature & Storage period (hour) & Color & Odor & Taste & Texture & Overall acceptability \\
\hline $28^{\circ} \mathrm{C}$ & 0 & $9.00 \pm 0.00^{\mathrm{d}}$ & $9.00 \pm 0.00^{\mathrm{d}}$ & $9.00 \pm 0.00^{\mathrm{d}}$ & $9.00 \pm 0.00^{\mathrm{d}}$ & $9.00 \pm 0.00^{\mathrm{d}}$ \\
& 24 & $7.60 \pm 0.12^{\mathrm{c}}$ & $7.05 \pm 0.26^{\mathrm{c}}$ & $7.65 \pm 0.53^{\mathrm{c}}$ & $6.85 \pm 0.46^{\mathrm{c}}$ & $7.35 \pm 0.66^{\mathrm{c}}$ \\
& 48 & $5.25 \pm 0.11^{\mathrm{b}}$ & $3.41 \pm 0.23^{\mathrm{b}}$ & $4.33 \pm 0.28^{\mathrm{b}}$ & $3.11 \pm 0.41^{\mathrm{b}}$ & $4.33 \pm 0.85^{\mathrm{b}}$ \\
$5^{\circ} \mathrm{C}$ & 72 & $2.86 \pm 0.32^{\mathrm{a}}$ & $1.68 \pm 0.48^{\mathrm{a}}$ & $1.52 \pm 0.72^{\mathrm{a}}$ & $1.85 \pm 0.52^{\mathrm{a}}$ & $1.63 \pm 0.12^{\mathrm{a}}$ \\
& 0 & $9.00 \pm 0.00^{\mathrm{a}}$ & $9.00 \pm 0.00^{\mathrm{a}}$ & $9.00 \pm 0.00^{\mathrm{a}}$ & $9.00 \pm 0.00^{\mathrm{d}}$ & $9.00 \pm 0.00^{\mathrm{a}}$ \\
& 24 & $8.70 \pm 0.29^{\mathrm{a}}$ & $8.55 \pm 0.23^{\mathrm{a}}$ & $8.75 \pm 0.43^{\mathrm{a}}$ & $8.58 \pm 0.16^{\mathrm{c}}$ & $8.70 \pm 0.26^{\mathrm{a}}$ \\
& 48 & $8.35 \pm 0.12^{\mathrm{a}}$ & $8.30 \pm 0.52^{\mathrm{a}}$ & $8.45 \pm 0.22^{\mathrm{a}}$ & $7.39 \pm 0.24^{\mathrm{b}}$ & $8.52 \pm 0.30^{\mathrm{a}}$ \\
& 72 & $8.04 \pm 0.26^{\mathrm{a}}$ & $8.11 \pm 0.42^{\mathrm{a}}$ & $8.26 \pm 0.15^{\mathrm{a}}$ & $6.32 \pm 0.30^{\mathrm{a}}$ & $8.43 \pm 0.14^{\mathrm{a}}$ \\
\hline
\end{tabular}


at room temperature. Fish burgers were highly acceptable even at the end of 24 hours of storage. However, after 48 and 72 hours it was found unacceptable because of a pungent and sour odor followed by a bad smell. On the other hand, at $5^{\circ} \mathrm{C}$ storage temperature the fish burger was observed to be more stable. The findings of differences in color, odor, taste, texture, and overall acceptability of fish singara prepared from Thai-Pangus stored at $28^{\circ} \mathrm{C}$ and $5^{\circ} \mathrm{C}$ temperature is shown in Table 8. Significant $(P<0.05)$ decline of sensory attributes was observed with the increase of storage time at room temperature. It was found acceptable even after 24 hours of storage but after that it was reported objectionable for consumption. Pungent to sour odor, peculiar bad smell, bacterial growth, and fungal growth were observed which made fish burgers highly unacceptable for eating. However, at refrigerated storage temperature the fish singara was perceived comparatively more stable. The color, odor, taste, and overall acceptability did not change noticeably $(P>0.05)$ even after 72 hours. The texture quality changed significantly after 48 and 72 hours $(P<0.05)$ but was considered satisfactory.

The results of this study are similar with the results of Koelkar and Pagarkar (2013). They evaluated organoleptic characteristics such as color, taste, odor, appearance, texture, and overall acceptability of fish balls prepared from Catla catla kept in chilled storage ( 0 to $\left.-2^{\circ} \mathrm{C}\right)$. They observed a declined trend of organoleptic scores (from 9.0 to 3.1) for the storage period of 0 to 12 days. Besides, they stated that fish balls in curry kept in chilled storage was not acceptable after 9 days. The color, odor and overall acceptability did not alter distinctly ( $P>0.05)$ even after 72 hours. No fungal growth was found after 72 hours. The textural quality and taste changed significantly $(P<0.05)$ at 48 and 72 hours but also considered as satisfactory. The findings of the present study are found parallel with the findings of Ejaz et al. (2009). They assessed the sensory quality of fish burgers formulated from Pangasius sutchi kept at room $\left(28^{\circ} \mathrm{C}\right)$ and refrigeration $\left(4^{\circ} \mathrm{C}\right)$ temperature. They observed that the sensory attributes decreased significantly $(P<0.05)$ throughout the storage period at room temperature. In contrast, the product was more stable at refrigerated temperature $\left(4^{\circ} \mathrm{C}\right)$. Huda et al. (2010) reported that the washing process increased the lightness of surimi-based products such as commercial fish balls. Sensory evaluation of balls from washed Indian mackerel mince revealed good scores for color, odor, taste, and acceptability (Alkuraieef et al., 2020).

\section{Bacterial Count Analysis}

The changes in bacterial count (CFU/g) of fish ball, fish burger and fish singara prepared from Thai Pangus in the room $\left(28^{\circ} \mathrm{C}\right)$ and in the refrigerator $\left(4^{\circ} \mathrm{C}\right)$ are given in Table 9. In both temperatures, the TPC (Total Plate Count) was increased significantly $(P<0.05)$ throughout the storage period. Preliminary bacterial count of fish balls was $4.25 \pm 0.34 \times 10^{4} \mathrm{CFU} / \mathrm{g}$. Bacterial growth in fish balls stored at room temperature increased rapidly $(P<0.05)$ with the progress of storage time and within 24 hours TPC increased to $6.30 \pm 0.41 \times 10^{5} \mathrm{CFU} / \mathrm{g}$, after 48 hours it was $1.53 \pm 0.14 \times 10^{8} \mathrm{CFU} / \mathrm{g}$ and after 72 hours these values reached to $3.85 \pm 0.52 \times 10^{9} \mathrm{CFU} / \mathrm{g}$. Although the same fish balls were stored at refrigerated temperatures, the growth patterns of the bacteria were

Table 7. Effect of storage temperature and period on sensory quality of fish burger prepared from Thai-Pangus ( $n=10)$. Data expressed as mean \pm SD.

\begin{tabular}{lcccccc}
\hline Storage temperature & Storage period (hour) & Color & Odor & Taste & Texture & Overall acceptability \\
\hline $28^{\circ} \mathrm{C}$ & 0 & $9.00 \pm 0.00^{\mathrm{d}}$ & $9.00 \pm 0.00^{\mathrm{d}}$ & $9.00 \pm 0.00^{\mathrm{d}}$ & $9.00 \pm 0.00^{\mathrm{d}}$ & $9.00 \pm 0.00^{\mathrm{d}}$ \\
& 24 & $7.60 \pm 0.12^{\mathrm{c}}$ & $7.05 \pm 0.26^{\mathrm{c}}$ & $7.65 \pm 0.53^{\mathrm{c}}$ & $6.85 \pm 0.46^{\mathrm{c}}$ & $7.35 \pm 0.66^{\mathrm{c}}$ \\
& 48 & $5.25 \pm 0.11^{\mathrm{b}}$ & $3.41 \pm 0.23^{\mathrm{b}}$ & $4.33 \pm 0.28^{\mathrm{b}}$ & $3.11 \pm 0.41^{\mathrm{b}}$ & $3.33 \pm 0.85^{\mathrm{b}}$ \\
$5^{\circ} \mathrm{C}$ & 72 & $2.86 \pm 0.32^{\mathrm{a}}$ & $1.68 \pm 0.48^{\mathrm{a}}$ & $1.52 \pm 0.72^{\mathrm{a}}$ & $1.85 \pm 0.52^{\mathrm{a}}$ & $1.63 \pm 0.12^{\mathrm{a}}$ \\
& 0 & $9.00 \pm 0.00^{\mathrm{a}}$ & $9.00 \pm 0.00^{\mathrm{a}}$ & $900 \pm 0.00^{\mathrm{b}}$ & $9.00 \pm 0.00^{\mathrm{c}}$ & $9.00 \pm 0.00^{\mathrm{a}}$ \\
& 24 & $8.65 \pm 0.19^{\mathrm{a}}$ & $8.49 \pm 0.33^{\mathrm{a}}$ & $8.62 \pm 0.13^{\mathrm{b}}$ & $8.46 \pm 0.26^{\mathrm{b}}$ & $8.67 \pm 0.27^{\mathrm{a}}$ \\
& 48 & $8.25 \pm 0.22^{\mathrm{a}}$ & $8.28 \pm 0.35^{\mathrm{a}}$ & $8.41 \pm 0.25^{\mathrm{b}}$ & $8.05 \pm 0.24^{\mathrm{b}}$ & $8.30 \pm 0.30^{\mathrm{a}}$ \\
& 72 & $8.04 \pm 0.26^{\mathrm{a}}$ & $8.11 \pm 0.42^{\mathrm{a}}$ & $7.19 \pm 0.15^{\mathrm{a}}$ & $7.33 \pm 0.31^{\mathrm{a}}$ & $8.20 \pm 0.22^{\mathrm{a}}$ \\
\hline
\end{tabular}

Different superscripts in each column represent significant difference $(P<0.05)$.

Table 8. Effect of storage temperature and period on sensory quality of fish singara prepared from Thai-Pangus $(n=10)$. Data expressed as mean \pm SD.

\begin{tabular}{lcccccc}
\hline Storage temperature & Storage period (hour) & Color & Odor & Taste & Texture & Overall acceptability \\
\hline $28^{\circ} \mathrm{C}$ & 0 & $9.00 \pm 0.00^{\mathrm{d}}$ & $9.00 \pm 0.00^{\mathrm{d}}$ & $9.00 \pm 0.00^{\mathrm{d}}$ & $9.00 \pm 0.00^{\mathrm{d}}$ & $9.00 \pm 0.00^{\mathrm{d}}$ \\
& 24 & $7.75 \pm 0.15^{\mathrm{c}}$ & $7.65 \pm 0.31^{\mathrm{c}}$ & $7.45 \pm 0.13^{\mathrm{c}}$ & $6.96 \pm 0.36^{\mathrm{c}}$ & $7.35 \pm 0.66^{\mathrm{c}}$ \\
& 48 & $5.63 \pm 0.21^{\mathrm{b}}$ & $3.31 \pm 0.53^{\mathrm{b}}$ & $4.39 \pm 0.23^{\mathrm{b}}$ & $3.35 \pm 0.63^{\mathrm{b}}$ & $3.63 \pm 0.85^{\mathrm{b}}$ \\
$5^{\circ} \mathrm{C}$ & 72 & $2.23 \pm 0.35^{\mathrm{a}}$ & $1.95 \pm 0.28^{\mathrm{a}}$ & $1.82 \pm 0.32^{\mathrm{a}}$ & $1.32 \pm 0.15^{\mathrm{a}}$ & $1.98 \pm 0.11^{\mathrm{a}}$ \\
& 0 & $9.00 \pm 0.00^{\mathrm{a}}$ & $9.00 \pm 0.00^{\mathrm{a}}$ & $9.00 \pm 0.00^{\mathrm{a}}$ & $9.00 \pm 0.00^{\mathrm{d}}$ & $9.00 \pm 0.00^{\mathrm{a}}$ \\
& 24 & $8.67 \pm 0.19^{\mathrm{a}}$ & $8.85 \pm 0.33^{\mathrm{a}}$ & $8.66 \pm 0.13^{\mathrm{a}}$ & $8.68 \pm 0.25^{\mathrm{c}}$ & $8.71 \pm 0.17^{\mathrm{a}}$ \\
& 48 & $8.25 \pm 0.35^{\mathrm{a}}$ & $8.64 \pm 0.27^{\mathrm{a}}$ & $8.52 \pm 0.32^{\mathrm{a}}$ & $7.10 \pm 0.32^{\mathrm{b}}$ & $8.63 \pm 0.31^{\mathrm{a}}$ \\
\hline
\end{tabular}


Table 9. Effect of the storage period on bacterial load (CFU/g) of fish ball, fish burger and fish singara prepared from Thai-Pangus stored at different storage temperature.

\begin{tabular}{lcccc}
\hline Storage temperature & Storage time (hour) & Fish Ball & Fish Burger & Fish Singara \\
\hline $28^{0} \mathrm{C}$ & 0 & $4.25^{\mathrm{a}} \pm 0.34 \times 10^{4}$ & $5.45^{\mathrm{a}} \pm 0.54 \times 10^{4}$ & $3.98^{\mathrm{a}} \pm 0.62 \times 10^{4}$ \\
& 24 & $6.30^{\mathrm{b}} \pm 0.41 \times 10^{5}$ & $3.89^{\mathrm{b}} \pm 0.25 \times 10^{6}$ & $7.35^{\mathrm{b}} \pm 0.74 \times 10^{6}$ \\
& 48 & $1.53^{\mathrm{c}} \pm 0.14 \times 10^{8}$ & $6.3^{\mathrm{c}} \pm 0.69 \times 10^{7}$ & $5.12^{\mathrm{c}} \pm 0.80 \times 10^{8}$ \\
$5^{\circ} \mathrm{C}$ & 72 & $3.85^{\mathrm{d}} \pm 0.52 \times 10^{9}$ & $1.93^{\mathrm{d}} \pm 0.84 \times 10^{9}$ & $6.21^{\mathrm{d}} \pm 0.38 \times 10^{9}$ \\
& 0 & $5.05^{\mathrm{a}} \pm 0.23 \times 10^{4}$ & $5.60^{\mathrm{a}} \pm 0.43 \times 10^{4}$ & $5.05^{\mathrm{a}} \pm 0.23 \times 10^{4}$ \\
& 24 & $7.35^{\mathrm{b}} \pm 0.63 \times 10^{4}$ & $4.15^{\mathrm{b}} \pm 0.74 \times 10^{5}$ & $4.12^{\mathrm{b}} \pm 0.76 \times 10^{4}$ \\
& 48 & $5.70^{\mathrm{c}} \pm 0.34 \times 10^{5}$ & $8.55^{\mathrm{c}} \pm 0.41 \times 10^{6}$ & $1.65^{\mathrm{c}} \pm 0.25 \times 10^{6}$ \\
& 72 & $8.12^{\mathrm{d}} \pm 0.82 \times 10^{6}$ & $7.25^{\mathrm{d}} \pm 0.79 \times 10^{7}$ & $4.35^{\mathrm{d}} \pm 0.43 \times 10^{7}$ \\
\hline
\end{tabular}

somewhat different. Correspondingly, initial bacterial count of fish singara was estimated $5.05 \pm 0.23 \times 10^{4}$ $\mathrm{CFU} / \mathrm{g}$. At room temperature, bacterial growth swiftly escalates $(P<0.05)$ with the increase of storage time and within 24 hours TPC increased to $7.35 \pm 0.74 \times 10^{6} \mathrm{CFU} / \mathrm{g}$, after 48 hours and after 72 hours these values reached to $6.21 \pm 0.38 \times 10^{9} \mathrm{CFU} / \mathrm{g}$. However, the same fish singara kept in the refrigerator revealed faintly changed bacterial progression. In this case, bacterial expansion speed was slower and during the 24 hours storage time no noticeable $(P<0.05)$ change were saw in TPC, after that bacterial growth steadily augmented significantly $(P<0.05)$ and after 72 hours the TPC extended to $4.35 \pm 0.43 \times 10^{7} \mathrm{CFU} / \mathrm{g}$ in fish singara.

In current research, the bacterial growth rate was lower and no noticeable change in TPC was observed during $24 \mathrm{~h}$ of storage, after which bacterial growth gradually increased $(P<0.05)$ and after 72 hours the TPC reached to $8.12 \pm 0.82 \times 10^{6} \mathrm{CFU} / \mathrm{g}$ in the fish ball. Current findings are parallel with the findings of Kamat (1999). He reported TPC of fish balls in curry prepared from mackerel stored in chilled temperature was $3.1 \times 10^{4}$ to $4.1 \times 10^{7} \mathrm{CFU} / \mathrm{g}$ during a storage period of 14 days. But Koelkar and Pagarkar (2013) recorded the TPC of the fish ball in curry prepared from Catla catla in chilled storage was increased from $1.8 \times 10^{2}$ to $2.4 \times 10^{4} \mathrm{CFU} / \mathrm{g}$ during a storage period of 12 days. Mote (2001) found the TPC values of chilled stored fish balls in spinach curry ranging from $1.70 \times 10^{4}$ to $5.70 \times 10^{7} \mathrm{CFU} / \mathrm{g}$ which is also consistent with results of the current study. Likewise, the earliest bacterial count of fish burgers was $5.45 \pm 0.54 \times 10^{4} \mathrm{CFU} / \mathrm{g}$. Bacterial growth in fish burger kept at room temperature quickly amplified $(P<0.05)$ with increasing storage time and within 24 hours TPC increased to $3.89 \pm 0.25 \times 10^{6} \mathrm{CFU} / \mathrm{g}$, after 48 hours it was $6.33 \pm 0.69 \times 10^{7} \mathrm{CFU} / \mathrm{g}$ and after 72 hours these values reached to $1.93 \pm 0.84 \times 10^{9} \mathrm{CFU} / \mathrm{g}$. Bacterial growth trend was slightly altered when identical fish burgers kept at $5^{\circ} \mathrm{C}$. In this case, bacterial development rate was slower and during the 24 hours storage time minor change were observed in TPC, after that, the growth of bacteria gradually increased significantly $(P<0.05)$ and after 72 hours the TPC reached to $7.25 \pm 0.79 \times 10^{7} \mathrm{CFU} / \mathrm{g}$ in fish burger. These results coincide with the results of Ejaz et al. (2009). They estimated the bacteria of the fish burger developed from Pangasius sutchi stored at room and refrigeration temperature. They reported that although the bacterial count increased significantly at both temperatures $(P<0.05)$, the growth pattern was slower at the refrigerated temperature. They recorded the bacterial count of fresh fish burger $1.58 \times 10^{4} \mathrm{CFU} / \mathrm{g}$ and after 72 hours at room temperature it increased to $5.9 \times 10^{9} \mathrm{CFU} / \mathrm{g}$ while at refrigeration temperature it increased to $2.1 \times 10^{7} \mathrm{CFU} / \mathrm{g}$. Microbiological count of fish mince and burger decreased with freezing time and maximum decrease was found during the first month of storage period (Mahmoudzadeh et al., 2010).

\section{Conclusion}

To conclude the study, it is found that the initial noticeable fresh sweetness of the food gradually becomes pungent and sour, and after 72 hours, fungal growth on the moist slimy surface, indicating a large growth of bacteria. An unpleasant odor was produced when stored for 48 hours. After 72 hours of room temperature stored products were found unacceptable for consumption. On the other hand, all products were more stable at refrigeration temperature $\left(5^{\circ} \mathrm{C}\right)$. In both storage temperatures, the bacterial count of all the products was increased significantly $(P<0.05)$ throughout the storage period. More research should go on preparation of value-added products from other lowcost fish on proximate composition, sensory attributes and microbial load of value-added products, feasibility study of commercial production.

\section{Acknowledgements}

Authors would like to express gratitude to the Department of Biochemistry and Chemistry, Sylhet Agricultural University, Sylhet, for providing logistic support to successfully complete the research work.

\section{References}

Akter, M., Islam, S. N., Reza, M. S., Shikha, F. H., \& Kamal, M. (2013). Quality evaluation of fish balls prepared from frozen stored striped catfish (Pangasianodon hypophthalmus). Journal Agroforestry and Environment, 7(1), 7-10.

Alkuraieef, A. N., Alsuhaibani, A. M., Alshawi, A. H., \& Aljahani, A. H. (2020). Effect of frozen storage on nutritional, microbial and sensorial quality of fish balls and fish fingers produced from Indian Mackerel. Current 
Research in Nutrition and Food Science, 8(3), 852- 861.

Association of Official Analytical Chemists (AOAC). (1990). Official Method of Analysis, 13th edition, Washington, D. C., 10-18.

Carter, G. R. (1979). Studies on Pasteurella multocida. A hemagglutination test for the identification of serological types. Journal of Veterinary Research, 16, 481-484.

Chowdhury, A. H., Chowdhury F., \& Rahman L. (2016). Marketing system of Tilapia fish in some selected areas of Bangladesh. Imperial journal of interdisciplinary research, 3 (1),

Chowdhury, M. A., Karim, M. A., Rahman, M. T., Shefat, S. H. T., Rahman, A., \& Hossain, M. A. (2019). Biodiversity assessment of indigenous fish species in the surma river of Sylhet Sadar, Bangladesh. Punjab University Journal of Zoology, 34(1), 73-77. https://doi.org/10.17582/journal.pujz/2019.34.1.73.77

De Silva, S. S., Amarasinghe, U. S., \& Nguyen, T. T. T. (2006) Better-practice approaches for culture-based fisheries development in Asia. Canberra. Australian Centre for International Agricultural Research, Monograph No. 120, 96.

De Silva, S. S., Nguyen, T. T. T., Abery, N. W., \& Amarasinghe, U. S. (2006). An evaluation of the role and impacts of alien finfish in Asian inland aquaculture. Aquaculture Research, 37: 1-17.

De Silva, S. S., Nguyen, T. T. T., Turchini, G. M., Amarasinghe, U. S., \& Abery, N. W. (2009). Alien species in aquaculture and biodiversity: a paradox in food production. Ambio, 38(1), 24-28.

Department of Fisheries (DoF). (2017). National Fish Week Compendium 2017 (in Bengali). Ministry of Fisheries and Livestock, Dhaka, Bangladesh, 144.

Ejaz, M. A., Shikha, F. H., \& Hossain, M. I. (2009). Preparation of fish burger from Pangus Catfish (Pangasius sutchi) and evaluation of quality and shelf life during different storage conditions. Progressive Agriculture, 20(1 \& 2), $153-162$.

Gopakumar, K. (1997). Tropical fishery products. Science Publication Inc., Enfield, USA, 190.

Hasan, R., Hossain, M. A., Islam, R., \& Iqbal, M. M. (2021). Does commercial probiotics improve the growth performance and hematological parameters of Nile tilapia, Oreochromis niloticus? Aquatic Research, 4(2), 160-168. https://doi.org/10.3153/AR21013

Hoque, M. S., Roy, S., Mukit, S. S., Rahman, M. B., \& Akter, S. (2021). Effects of Pangasius (Pangasius hypophthalmus) and Skipjack Tuna (Sarda orientalis) mince blend on the quality of fish products: Ways to utilize resources and nutrition in Bangladesh. Food Science \& Nutrition.

Hossain, M. A. (2021). Some Aspects of Reproduction in Amblypharyngodon mola from Sylhet, Northeast Bangladesh. Aquatic Sciences and Engineering, 36(3), 140-145. https://doi.org/10.26650/ASE2020858534

Hossain, M. A., Akter, M., \& Iqbal, M. M. (2017). Diversity of Fish Fauna in Kusiara River (Fenchungonj Upazilla), Northeast Bangladesh. Journal of Aquaculture in the Tropics, 32(1), 1-13.

Hossen, M. A., Hossain, M. A., Hasan, A. K. M. M., Das, B., Mian, S., \& Iqbal, M. M. (2021). Observation of Embryonic and Larval Developmental Stages in Endangered Nona Tengra (Mystus gulio) Induced with S-GnRHa. Punjab University Journal of Zoology, 36(1), 91-99. https://doi.org/10.17582/journal.pujz/2021.36.1.91.99
Huda, N., Shen, Y. H., Huey, Y. L., \& Dewi, R. S. (2010) Ingredients, proximate composition, colour and textural properties of commercial Malaysian fish balls. Pakistan Journal of Nutrition, 9(12), 1183-1186.

Iqbal, M., Kanon, M. H., Hossain, M. A., Hossain, A., Nasren, S., Islam, M. J., \& Rahman, M. A. (2015). Diversity of indigenous fish species in Konoskhaihaor, Northeast Bangladesh. Punjab University Journal of Zoology, 30(2), 73-79.

Kolekar, A. D., \& Pagarkar, A. U. (2013). Quality evaluation of ready-to-eat fish ball in curry. SAARC Journal of Agriculture, 11(1), 35-43.

Lithi, U. J., Faridullah, M., Uddin, M. N., Mehbub, M. F., \& Zafar, M. A. (2020). Quality evaluation of mince-based fish burger from tilapia (Oreochromis mossambicus) during frozen storage. Journal of the Bangladesh Agricultural University, 18(2), 524-528.

Mahmoudzadeh, M., Motallebi, A.A., Hosseini, H., Haratian, P., Ahmadi, H., Mohammadi, M., \& Khaksar, R. (2010). Quality assessment of fish burgers from deep flounder (Pseudorhombus elevatus) and brushtooth lizardfish (Sauridaundos quamis) during storage at-18으. Iranian Journal of Fisheries Sciences, 9(1), 111-126.

Mian, S., Papree, S. D., Dey, T., Hossain, M. A., Iqbal, M. M., Abol-Munaf, A. B., \& Islam, M. S. (2017). Some Reproductive Aspects of Freshwater Garfish, Xenentodon cancila (Hamilton, 1822) from North-East Bangladesh. Journal of Fisheries and Aquatic Science, 12(2), 82-89. https://doi.org/10.3923/jfas.2017.82.89

Ninan, G., Bindu, J., \& Joseph, J. (2008). Frozen storage studies of minced based products developed from tilapia (Oreochromis mossambicus). Fishery Technology, 45(1), 35-42.

Nowsad, A. A., \& Hoque, M. S. (2007). New fish sausage prepared from unwashed mince blend of low-cost marine fish. Asian Fisheries Science, 22:347-357.

Nowsad, A. A., Hoque, M. E., \& Sarker, F. C. (2000a). First report of the formulation and development of fish sausage from underutilized marine fish in Bangladesh: fish sausage from sea catfish and Bombay duck. Bangladesh Journal of Fisheries, 23(2), 107-112.

Nowsad, A. A., Kamal, M., \& Hossain, M. I. (1994). Seafood Resource Availability, Utilization and Research in Bangladesh. Proceeding of the international Seafood Research Meeting of the Mie University. Mie Academic Press, 109-126.

Nowsad, A. A., Kanoh, S., \& Niwa, E. (2000b). Thermal gelation characteristics of breast and thigh muscles of spent hen and broiler and their surimi. Meat Science, 54: 169-75.

Pires, D. R., Jamas, A. L. A., Amorim, E., Azevedo-Meleiro, C. H., Silva, P. P. O., Oliveira G. M. (2017). Chemical characterization of marine fish of low-commercial value and development of fishburger. Pesquisa Agropecuária Brasileira - PAB, 52 (11), 1098. https://doi.org/10.1590/S0100204X201700110001.5

Rahman, M. A., Hossain, M. A., Ullah, M. R., \& Iqbal, M. M. (2020). Reproductive biology of Gagora catfish (Arius gagora) at Meghna river system, Kushiara. International Journal of Aquatic Biology, 8(6), 383-395.

Vanitha, M., Dhanapal, K., Sravani, K., Vidya, G., \& Sagar, R. (2013). Quality evaluation of value-added mince-based products from catla (Catla catla) during frozen storage. International Journal of Environmental Science and Technology, 2(3): 487-501. 